\title{
Impact of environmental and soil factors in the prediction of soil carbon dioxide emissions under different tillage systems
}

\author{
István Mihály Kulmány ${ }^{1}$, Zsolt Giczi ${ }^{1}$, Ana Beslin ${ }^{2}$, Laszló Bede ${ }^{1}$, Renátó Kalocsai ${ }^{1}$, Viktória Vona ${ }^{1}$ \\ ${ }^{1}$ Faculty of Agricultural and Food Sciences, Széchenyi István University, Mosonmagyaróvár 9200, Györ-Moson-Sopron \\ county, Hungary \\ ${ }^{2}$ Faculty of Sciences, Department of Mathematics and Informatics, University of Novi Sad, Novi Sad 21102, South Bačka \\ District, Republic of Serbia
}

Corresponding author: István Mihály Kulmány,Ph.D. Candidate, email: kulmany.istvan@sze.hu

\begin{abstract}
Understanding the roles of natural drivers in greenhouse gas (GHG) emissions of arable fields is crucial for adequate agricultural management. This study investigated the combined effect of two tillage treatments (NT - no-tillage; CT - tillage with mouldboard ploughing) and environmental (air pressure, air temperature) and soil factors (total organic carbon, gravimetric water content and soil penetration resistance) on soil carbon dioxide $\left(\mathrm{CO}_{2}\right)$ emissions in maize in 2020 and 2021. The soil tubes required for the laboratory measurement were derived from three different altitudes of the two differently cultivated fields from Fejér county, Hungary. The typical soil type was Chernozem in both fields. At the time of soil sampling, soil penetration resistance was measured with a 06.15SA Penetrologger in 10 repetitions. To preserve the moisture content of the soil columns during the investigation, moisture replenishment was performed equal to the degree of weekly theoretical evapotranspiration. Emissions measurements of soil columns were performed by close chamber technique for five weeks from sampling, 15 times, in 3 repetitions in laboratory conditions. The data were evaluated by two-way ANOVA, followed by the Tukey HSD multiple comparison test and two-tailed Student's T-test at a significance level of $\mathrm{p}<0.05$. The combined effect of environmental factors on soil carbon dioxide emissions was investigated using stepwise multiple linear regression. It has been proved that the observed difference between soil penetration resistance and soil carbon dioxide emissions was significant between CT and NT cultivation at different stages of the growing season. The analysis of the interaction of the experimental factors revealed that the combined effect of soil penetration resistance, total organic carbon and moisture content in tillage system (adjusted $\mathrm{R}^{2}=0.92$ at a significance level of $\mathrm{p}=0.05$ ) in 2020, while the combined effect of moisture content and air temperature in the no-tillage system (adjusted $\mathrm{R}^{2}=0.79$ at a significance level of $\mathrm{p}=0.085$ ) has the most significant effect on soil $\mathrm{CO}_{2}$ emissions in 2020. In 2021, the air temperature for the tillage system (adjusted $\mathrm{R}^{2}=0.74$ at a significance level of $\mathrm{p}=0.05$ ) and the combined effect of air temperature and pressure for no-tillage systems (adjusted $\mathrm{R}^{2}=0.69$ at a significance level of $\mathrm{p}=0.1$ ) played an important role in soil $\mathrm{CO}_{2}$ emissions. These observations highlight that different soil and environmental factors of different tillage significantly impact the soil carbon dioxide emissions in different years.
\end{abstract}

Keywords - soil $\mathrm{CO}_{2}$ emissions, TOC, soil penetration resistance, soil water content, air temperature

Received: January 1, 2022.

Accepted: January 19, 2022

\section{INTRODUCTION}

One of the main challenges facing the world today is to reduce greenhouse gas (GHG) emissions. The most harmful greenhouse gases to the environment are carbon dioxide
$\left(\mathrm{CO}_{2}\right)$, methane $\left(\mathrm{CH}_{4}\right)$ and nitrous oxide $\left(\mathrm{N}_{2} \mathrm{O}\right) .55 \%$ of total GHG emissions are related to anthropogenic activities, and $22 \%$ of total GHG are originated from the agricultural sector (Montzka et al., 2011, Tubiello et al., 2013) in 2008. The absolute emissions of agriculture and related land use had 
been stagnated at the same level since 2008, but its share from global GHG emissions slight decreased from $22 \%$ to $17 \%$ between 2008-2018 (FAO, 2020). This is mainly due to the fact that the emissions from other sectors had been grown at relatively faster rates. Its most important source is the cultivation of agricultural soils (Bockisch, 2010), responsible for a significant portion of GHG emissions from agriculture (US.EPA, 2012).

Globally, the main issue is the steady rise of atmospheric concentrations of carbon dioxide. According to Lal et al., (2007), the $\mathrm{CO}_{2}$ concentration increased by almost $35 \%$, from $280 \mathrm{ppm}$ to $377 \mathrm{ppm}$ between 1750 and 2004. According to the latest data, the annual average $\mathrm{CO}_{2}$ concentration for 2021 could be around 416.3 ppm (Lovenduski et al., 2021). The $76 \%$ of global $\mathrm{CO}_{2}$ is emitted from the use of fossil fuels, industrial processes, deforestation and other land-use change (IPCC, 2014). Due to their environmental impact, agricultural activities significantly contribute to $\mathrm{CO}_{2}$ emissions (Nawaz et al., 2017). According to OWID (2021), agricultural activities have been responsible for annual 3 billion tonnes of $\mathrm{CO}_{2}$ since 2007.

Soils are the largest terrestrial pool of carbon (C), storing $2344 \mathrm{Pg} \mathrm{C}$ ( $1 \mathrm{Pg}=1$ billion tonnes) of soil organic carbon in the top $3 \mathrm{~m}$ (Jobbágy and Jackson, 2000). It is almost twice more than in the atmosphere and three times higher than terrestrial vegetation (Schlesinger, 1990). The agricultural soil $\mathrm{CO}_{2}$ emissions are affected many soil properties, environmental factors and agricultural management practices (Smith et al., 2008). Significantly, the tillage practices are the primary source that accounted for the release of carbon dioxide through the organic matter decomposition (Rastogi et al., 2002). The introduction of no-tillage farming systems is now widely accepted as carbon sequestration and climate change mitigation tillage practice (Baker et al., 2007; Powlson et al., 2014). However, Hendrix et al., (1998) and Oorts et al., (2007) revealed that the untilled soil emitted $13 \%$ greater $\mathrm{CO}_{2}$ to the air than tilled soil.

The other major factor behind the soil $\mathrm{CO}_{2}$ emissions is the climate factor. Changes in temperature and precipitation of soil can affect soil $\mathrm{CO}_{2}$ emissions (Ray et al., 2020). Soil $\mathrm{CO}_{2}$ emissions immediately respond to the change of soil and air temperature, soil moisture and air pressure (Zhang et al., 2006; Ren et al., 2017). According to Groffman et al., (2006), the effect of environmental factors on $\mathrm{CO}_{2}$ emissions varies from season to season.

Laboratory approaches can be used to monitor the effect of these factors on soil $\mathrm{CO}_{2}$ emissions by changing one parameter while others are kept constant (Schaufler et al., 2010). A comparison of soils from different climatic zones by Schaufler et al., (2010), and soils from different cultivation under controlled conditions by Gritsch et al., (2015) set a good example.

Further research is required to understand better the impact of different tillage systems on soil $\mathrm{CO}_{2}$ emissions. Thus, the main aim of this research was (1) to monitor the $\mathrm{CO}_{2}$ emissions of tilled and untilled soils in laboratory conditions during two growing seasons; (2) to evaluate the impact of the environmental and soil factors on soil $\mathrm{CO}_{2}$ emissions and (3) to develop a general modelling approach to predict the $\mathrm{CO}_{2}$ emissions of different cultivated soils.

\section{MATERIALS AND Methods}

\section{Experiment location}

The research was conducted in two neighbouring fields (15 and $48 \mathrm{ha}$ ) in Fejér county, Hungary (Figure 1). According to Marosi and Somogyi (1990), the regional climate is characterised by a temperate climate with a mean annual temperature of $10,2-10,4{ }^{\circ} \mathrm{C}$. On the contrary, the mean temperature during the growing season was $12.9-13.1{ }^{\circ} \mathrm{C}$ in 2020 and $13.7-13.9^{\circ} \mathrm{C}$ in 2021 . The annual average rainfall was $500-550 \mathrm{~mm}$ in 2020 and $370-420 \mathrm{~mm}$ in 2021.

The T1 field (48 ha) is cultivated conventionally, while the T2 (15 ha) has been cultivating under a no-tillage system since 2019. The arable fields are characterized by Chernozem brown forest soil with loam and clay texture, and the parent material was loess.

\section{Soil sampling and their laboratory analysis}

The laboratory analyses were carried out based on the Hungarian standards (Buzás et al., 1993). The following parameters were analysed:

- $\mathrm{pH}$ (KCl, potentiometric method; MSZ-08-0206-2-:1978)

- Soil organic matter - SOM (wet combustion, Turin method)

- Nitrate, nitrite ( $\mathrm{KCl}$ soluble)

- $\mathrm{P}_{2} \mathrm{O}_{5}$ (ammonium-lactate soluble),

- $\mathrm{K}_{2} \mathrm{O}$ (ammonium-lactate soluble),

- Humus layer thickness - Pürckhauer type soil core sampler

- Particle size distribution (Laser diffractometry, Fritsch

Analysette 22 Microtech Plus)

\section{Laboratory experiment}

The timing of the sampling dates in 2020 was influenced by the implementation of the travel ban against the spread of COVID-19. Soil samples were taken at three locations of each experimental field in August and October 2020 and in March and August 2021 during the growing season of maize, considering the altitude differences and where average dose seeding (72.000 seed/ha) and fertiliser treatment $(120 \mathrm{kgN} / \mathrm{ha})$ was applied (Figure 1). Cold-rolled steel tubes with $27 \mathrm{~cm}$ high, $8 \mathrm{~cm}$ in diameter and 483.85 $\pm 2,28$ grams (g) weight was used for the soil sampling. The top and bottom of the soil tubes were sealed with a $9 \mathrm{~cm}$ diameter stainless-steel cap $68.61 \pm 0.02 \mathrm{~g}$ weight to preserve the soil structure and soil moisture content until their delivery to the laboratory. The height of the soil columns was 20 centimetres $(\mathrm{cm})$ in the soil tubes in each case.

Before measuring carbon dioxide emissions of soil tubes, their weights were weighed. The stainless-steel caps were eliminated from the top and the bottom of the soil tubes, and 
bottom parts were sealed with geotextile. The soil tubes were then placed on a tray to allow for flowing out the extra water at the bottom of the tubes during irrigation. From the second week of the laboratory measurements, weekly moisture replenishment was performed at the soil tubes according to the degree of weekly potential evapotranspiration. Using this irrigation strategy, the moisture content of the soil tubes changed by \pm 5 percentage point compared to the moisture content at the time of sampling. The water was replenished every 15 millilitres to avoid the soil compaction in tubes caused by moisture replenishment. It was necessary because the water on the surface of the soil tubes could not flow away. Thus, the weight of the accumulating rainwater could have changed the properties of the soil, such as porosity or permeability (Busscher et al., 2002). It eliminates the permeability of the pores and impedes the free movement of gas and water in the soil, thus reducing $\mathrm{CO}_{2}$ emissions of the soil tubes (Novara et al., 2012).

To calculate the moisture replenishment, the Dunay - Posza - Varga - Haszonits equitation (1) was applied (Dunay et al., 1968), which can be used to calculate the daily potential evapotranspiration (PET) considering the daily air temperature and relative humidity:

$$
\operatorname{PET}(\mathrm{mm} / \mathrm{day})=\frac{1-\mathrm{f}}{2-\mathrm{f}} * \mathrm{t}
$$

where:

PET - potential evapotranspiration

$\mathrm{f}$ - daily average of relative humidity (\%)

$\mathrm{t}$ - daily average of air temperature $\left({ }^{\circ} \mathrm{C}\right)$

After measuring soil tubes $\mathrm{CO}_{2}$ emissions, the weight of the soil tubes was measured and their initial gravimetric water content (GWC) was determined (Black, 1965).

\section{Measurement of the carbon dioxide emissions of soil tubes}

Table 1. Structure of the most important data in subsets for building models

\begin{tabular}{|c|c|c|c|c|c|}
\hline \multicolumn{6}{|c|}{ Models } \\
\hline Variables & Content of variable & Till20 & $\begin{array}{l}\text { No- } \\
\text { Till20 }\end{array}$ & Till21 & $\begin{array}{l}\text { No- } \\
\text { Till21 }\end{array}$ \\
\hline TOC & $\begin{array}{l}\text { total organic carbon [\% by weight] at } \\
\text { sampling time }\end{array}$ & + & + & + & + \\
\hline AP & $\begin{array}{l}\text { average daily air pressure }[\mathrm{kPa}] \text { at the } \\
\text { measurements time }\end{array}$ & + & + & + & + \\
\hline GWC & $\begin{array}{l}\text { gravimetric water content } \\
\text { [mass/mass\%] at sampling time }\end{array}$ & + & + & + & + \\
\hline PR & $\begin{array}{l}\text { average soil penetration resistance at } \\
\text { sampling time }[\mathrm{MPa}]\end{array}$ & + & + & + & + \\
\hline AT & $\begin{array}{l}\text { average daily temperature }\left[{ }^{\circ} \mathrm{C}\right] \text { at the } \\
\text { measurements time }\end{array}$ & + & + & + & + \\
\hline $\mathrm{CO}_{2}$ & $\begin{array}{l}\text { average daily carbon-dioxide } \\
\text { emission }\left[\mu \mathrm{mol}^{*} \mathrm{~m}^{-2 *} \mathrm{~s}^{-1}\right] \text { at } \\
\text { measurements time }\end{array}$ & + & + & + & + \\
\hline
\end{tabular}

The laboratory $\mathrm{CO}_{2}$ emissions measurement lasted for five weeks after soil sampling. Because of the proper moisture replenishment applied, the $\mathrm{CO}_{2}$ emissions had low volatility during the five weeks. Before starting the measurements, the top of the soil tubes was covered with a cap. The emission of soil tubes was measured with a well-known close chamber technique (Gritsch et al., 2015, Oertel et al., 2012) 15 times in 3 repetitions at laboratory temperature (AT) and air pressure (AP). During the measurements, the soil tubes were kept plant-free.

\section{Field measurements}

The soil penetration resistance (PR) was measured with a 06.15SA Penetrologger (EIJKELKAMP, Netherlands) at a maximum velocity of $2 \mathrm{~cm} / \mathrm{s}$ with a $2 \mathrm{~cm}^{2}$ cone size in 10 repetitions per point at the soil sampling time. The distance between the location of the measurements $(50-75 \mathrm{~cm})$ was determined according to Campbell and O'Sullivan, (1991) and the Dutch standard (NEN 5140, 1996).

Soil samples were collected from the $0-15 \mathrm{~cm}$ layer of the topsoil from no-till (T2) and tillage (T1) farming systems to determine the total organic carbon (TOC) content (Figure 1). The standard MSZ-08-0210-77 was used to determine TOC in the laboratory (MSZ -08-0210-77, 1977).

\section{Selecting variables for developing predictive models}

Evaluating the prognostic properties of the developed linear models is feasible when the models are built and verified based on the same dependent and independent variables. The detailed definitions of independent and dependent variables built in the regression models are presented in Table 1. 


\section{Statistical analyses}

All statistical analyses were carried out using Microsoft Excel (2021) and its Data Analysis ToolPak. In the first step, the soil heterogeneity in two research fields was analysed. In the second step, the observed soil and environmental properties were described with arithmetic mean and standard error. In the third step, after testing the homogeneity of variance of groups (Levene, 1960), a two-sample t-test assuming equal variances (Fisher, 1925) was applied to compare the means of soil $\mathrm{CO}_{2}$ emissions of different farming systems. In the fourth step, Pearson correlation analysis was used for the determination of the relationship between the mean soil $\mathrm{CO}_{2}$ emissions and other continuous variables, i.e., air temperature (AT), air pressure (AP), gravimetric water content (GWC), total organic carbon (TOC) and soil penetration resistance (PR). In the fifth step, stepwise multiple linear regression was performed onto the average values to explain the relationship between independent variables (AT, AP, GWC, TOC, PR) and the tested dependent variable (soil $\mathrm{CO}_{2}$ emissions) (Sellam and Poovammal, 2016). The variables whose statistical significance at the level of $\mathrm{p}=0,1$ was not confirmed have been eliminated from the models. In the sixth step, the multicollinearity between independent variables (Kutner et al., 2004) integrated into the models were tested with calculating the Variance Inflation Factor (VIF):

$$
V I F=\frac{1}{1-R_{a d j}^{2}}
$$

where:

$\mathrm{R}^{2}$ adj - adjusted $\mathrm{R}^{2}$.

In the seventh step, determining the accuracy of the forecasts was carried out by calculating the values of the forecasting properties of the models, such as (Niazian et al., 2018; Piekutowska et al., 2021):

$\mathrm{RAE}$ - relative approximation error;

$$
\mathrm{RAE}=\sqrt{\frac{\sum_{\mathrm{i}=1}^{\mathrm{n}}\left(\mathrm{y}_{\mathrm{i}}-\hat{\mathrm{y}}_{\mathrm{i}}\right)^{2}}{\sum_{\mathrm{i}=1}^{\mathrm{n}}\left(\mathrm{y}_{\mathrm{i}}\right)^{2}}}
$$

RMSE - root mean square error;

$$
\text { RMSE }=\sqrt{\frac{\sum_{i=1}^{n}\left(y_{i}-\hat{y}_{i}\right)^{2}}{n}}
$$

MAE - mean absolute error;

$$
\mathrm{MAE}=\frac{1}{\mathrm{n}} \sum_{\mathrm{i}=1}^{\mathrm{n}}\left\lfloor\mathrm{y}_{\mathrm{i}}-\hat{y}_{\mathrm{i}}\right\rfloor
$$

MAPE - mean absolute percentage error;

where:

$$
\mathrm{MAPE}=\frac{1}{\mathrm{n}} \sum_{\mathrm{i}=1}^{\mathrm{n}}\left\lfloor\frac{\mathrm{y}_{\mathrm{i}}-\hat{y}_{\mathrm{i}}}{\hat{y}_{\mathrm{i}}}\right\rfloor \times 100 \%
$$

where:

$$
\begin{aligned}
& \mathrm{n}-\text { number of observations, } \\
& \text { yi } \neg-\text { actual values obtained during the tests, } \\
& \hat{\mathrm{y}}-\text { values determined by the model. }
\end{aligned}
$$

\begin{tabular}{|c|c|c|c|c|c|c|c|c|}
\hline Field & Variables & Mean & Median & SD & $\mathbf{C V}$ & Min & Max & Range \\
\hline \multirow{10}{*}{ T1 } & Elevation (m) & 169.00 & 169.18 & 1.75 & 0.01 & 166.37 & 171.14 & 4.31 \\
\hline & $\mathrm{pH}(\mathrm{KCl})$ & 7.00 & 7.19 & 0.44 & 0.06 & 6.15 & 7.37 & 1.22 \\
\hline & Humus layer thickness (cm) & 39.29 & 35.00 & 7.87 & 0.20 & 35.00 & 55.00 & 20.00 \\
\hline & SOM (\% by weight) & 2.13 & 2.00 & 0.39 & 0.18 & 1.60 & 2.70 & 1.10 \\
\hline & Sand $(\%)$ & 16.66 & 16.31 & 6.37 & 0.38 & 9.77 & 26.05 & 16.29 \\
\hline & Silt (\%) & 77.42 & 78.34 & 5.76 & 0.07 & 68.70 & 83.80 & 15.10 \\
\hline & Clay $(\%)$ & 5.92 & 5.72 & 0.81 & 0.14 & 5.25 & 7.50 & 2.25 \\
\hline & $\mathrm{N}(\mathrm{mg} / \mathrm{kg})$ & 10.14 & 10.00 & 2.04 & 0.20 & 7.00 & 13.00 & 6.00 \\
\hline & $\mathrm{K}_{2} \mathrm{O}(\mathrm{mg} / \mathrm{kg})$ & 253.57 & 266.00 & 47.35 & 0.19 & 159.00 & 305.00 & 146.00 \\
\hline & $\mathrm{P}_{2} \mathrm{O}_{5}(\mathrm{mg} / \mathrm{kg})$ & 56.29 & 53.00 & 22.51 & $\mathbf{0 . 4 0}$ & 29.00 & 93.00 & 64.00 \\
\hline \multirow{10}{*}{$\mathbf{T 2}$} & Elevation $(\mathrm{m})$ & 176.05 & 176.64 & 2.28 & 0.01 & 172.37 & 179.78 & 6.89 \\
\hline & $\mathrm{pH}(\mathrm{KCl})$ & 7.11 & 7.12 & 0.15 & 0.02 & 6.88 & 7.30 & 0.42 \\
\hline & Humus layer thickness $(\mathrm{cm})$ & 58.33 & 60.00 & 14.79 & 0.25 & 35.00 & 90.00 & 55.00 \\
\hline & SOM (\% by weight) & 1.86 & 1.80 & 0.30 & 0.16 & 1.50 & 2.50 & 1.00 \\
\hline & Sand $(\%)$ & 15.77 & 18.73 & 7.06 & 0.45 & 2.28 & 24.38 & 22.10 \\
\hline & Silt (\%) & 77.93 & 75.69 & 6.16 & 0.08 & 70.94 & 90.32 & 19.38 \\
\hline & Clay $(\%)$ & 6.30 & 6.19 & 1.02 & 0.16 & 4.68 & 7.52 & 2.84 \\
\hline & $\mathrm{N}(\mathrm{mg} / \mathrm{kg})$ & 19.78 & 15.00 & 9.11 & 0.46 & 10.00 & 34.00 & 24.00 \\
\hline & $\mathrm{K}_{2} \mathrm{O}(\mathrm{mg} / \mathrm{kg})$ & 321.56 & 301.00 & 63.21 & 0.20 & 255.00 & 460.00 & 205.00 \\
\hline & $\mathrm{P}_{2} \mathrm{O}_{5}(\mathrm{mg} / \mathrm{kg})$ & 184.00 & 183.00 & 85.34 & 0.46 & 65.00 & 365.00 & 300.00 \\
\hline
\end{tabular}

\section{RESULTS}

\section{Variability of soil properties}

Table 2 shows the results of the descriptive statistics of soil properties. T2 field (Mean: $176 \mathrm{~m}$ ) is situated higher than the T1 field (Mean: $169 \mathrm{~m}$ ).

Table 2. Descriptive statistics of soil properties CV stands for coefficient of variation. CVs larger than 0.3 are highlighted. 
A West direction towards the East downwards slope is found in the T2 field while the T1 field has a hilly terrain (Figure 1). The higher points were eroded due to the elevation differences in the T1 field. It resulted that the humus layer was shallow $(30-40 \mathrm{~cm})$. The soil was accumulated on the deeper parts of the field with a humus layer of $90 \mathrm{~cm}$. There are minor differences in the elevation, but the soil was compacted in some parts of the T2 field. According to the classification of Wilding et al., (1994), the high variability was identified in terms of the T1 field: sand and $\mathrm{P}_{2} \mathrm{O}_{5}$, while
Sand, $\mathrm{N}$ and $\mathrm{P}_{2} \mathrm{O}_{5}$ had high variability in the case of $\mathrm{T} 2$ field. There was no significant difference between the two research fields in $\mathrm{pH}$ and SOM content.

\section{Descriptive statistics of measured factors}

Table 3. shows the results of the descriptive statistics of measured factors.

Table 3. Descriptive statistics (mean \pm standard error) of total organic carbon (TOC), air pressure (AP) and temperature (AT), soil penetration resistance (PR) and gravimetric water content (GWC)

\begin{tabular}{|c|c|c|c|c|c|c|c|c|}
\hline \multirow{3}{*}{$\begin{array}{l}\frac{0}{0} \\
\frac{\pi}{3} \\
\frac{\pi}{3}\end{array}$} & \multicolumn{4}{|c|}{2020} & \multicolumn{4}{|c|}{2021} \\
\hline & \multicolumn{2}{|c|}{ August } & \multicolumn{2}{|c|}{ October } & \multicolumn{2}{|c|}{ March } & \multicolumn{2}{|c|}{ August } \\
\hline & $\begin{array}{l}\text { No-till } \\
\text { farming } \\
\text { system }\end{array}$ & $\begin{array}{l}\text { Tillage } \\
\text { farming } \\
\text { system }\end{array}$ & $\begin{array}{l}\text { No-till } \\
\text { farming } \\
\text { system }\end{array}$ & $\begin{array}{l}\text { Tillage } \\
\text { farming } \\
\text { system }\end{array}$ & $\begin{array}{l}\text { No-till } \\
\text { farming } \\
\text { system }\end{array}$ & $\begin{array}{l}\text { Tillage } \\
\text { farming } \\
\text { system }\end{array}$ & $\begin{array}{l}\text { No-till } \\
\text { farming } \\
\text { system }\end{array}$ & $\begin{array}{l}\text { Tillage } \\
\text { farming } \\
\text { system }\end{array}$ \\
\hline TOC & $5.4 \pm 0.32 \mathrm{a}$ & $5.6 \pm 0.20 \mathrm{a}$ & $3.8 \pm 0.09 \mathrm{a}$ & $4.1 \pm 0.21 \mathrm{a}$ & $3.8 \pm 0.21 \mathrm{a}$ & $3.8 \pm 0.30 \mathrm{a}$ & $4.4 \pm 0.11 \mathrm{a}$ & $3.6 \pm 0.48 b$ \\
\hline AP & $100.2 \pm 1.20$ & $100.2 \pm 1.81$ & $100.7 \pm 4.36$ & $100.7 \pm 2.52$ & $100.3 \pm .81$ & $100.3 \pm 1.85$ & $100.4 \pm 0.88$ & $100.4 \pm 1.25$ \\
\hline GWC & $13.6 \pm 0.01 \mathrm{a}$ & $11.3 \pm 0.01 \mathrm{~b}$ & $14.8 \pm 0.01 \mathrm{a}$ & $16.1 \pm 0.00 \mathrm{~b}$ & $18.0 \pm 0.01 \mathrm{a}$ & $17.5 \pm 0.01 \mathrm{a}$ & $13.4 \pm 0.02 \mathrm{a}$ & $11.7 \pm 0.01 \mathrm{~b}$ \\
\hline PR & $1.4 \pm 0.08 \mathrm{a}$ & $0.9 \pm 0.17 b$ & $0.9 \pm 0.06 \mathrm{a}$ & $0.7 \pm 0.05 b$ & $1.4 \pm 0.07 \mathrm{a}$ & $0.4 \pm 0.04 \mathrm{~b}$ & $1.5 \pm 0.12 \mathrm{a}$ & $1.4 \pm 0.06 \mathrm{a}$ \\
\hline AT & $22.4 \pm 0.03$ & $22.3 \pm 0.01$ & $20.1 \pm 0.08$ & $19.2 \pm 0.12$ & $18.6 \pm 0.13$ & $18.4 \pm 0.04$ & $22.1 \pm 0.10$ & $22.3 \pm 0.03$ \\
\hline
\end{tabular}

The different letters show the significance difference calculating by two-tailed Student's T-test.

No significant difference was found between no-till and tillage farming systems in total organic carbon (TOC) content until March 2021. A significantly higher TOC content was observed in the no-till farming system $(4.4 \pm 0.11)$ compering to the tillage farming systems (3.6 \pm 0.48$)$ in August 2021. The no-till farming systems had higher soil penetration resistance (PR). A significant difference was found in three of four measurement cases in terms of PR. In two of three measurement cases, the gravimetric water content (GWC) was significantly higher in the no-till farming system. However, the soil moisture content was significantly higher $(16.1 \pm 0.00)$ in the tillage farming system in October 2020 than in the no-tillage system. Environmental factors such as air temperature (AT) and air pressure (AP) did not differ during the measurements.

\section{Soil $\mathrm{CO}_{2}$ emissions under different soil management practices}

The carbon dioxide $\left(\mathrm{CO}_{2}\right)$ emissions of soil columns showed significant differences between the tillage systems during the growing season (Figure 1). The soil $\mathrm{CO}_{2}$ emissions from notill farming systems were $108.05 \pm 7.68 \mu \mathrm{mol} \mathrm{m} \mathrm{m}^{-2} \mathrm{~s}^{-1}$ in August, which was significantly higher than for tillage farming systems $\left(80.39 \pm 3.39 \mu \mathrm{mol} \mathrm{m} \mathrm{m}^{-2} \mathrm{~s}^{-1}\right)$. Contrary to the $\mathrm{CO}_{2}$ emissions in August, no significant difference was found between the no-till and tillage farming systems. The highest $\mathrm{CO}_{2}$ emissions were observed in the no-till farming system $\left(99,36 \pm 3.66 \mu \mathrm{mol} \mathrm{m} \mathrm{m}^{-2} \mathrm{~s}^{-1}\right)$, while the $\mathrm{CO}_{2}$ emissions were $96.55 \pm 3.07 \mu \mathrm{mol} \mathrm{m}^{-2} \mathrm{~s}^{-1}$ in tillage farming system in October.

In March 2021, although the soil $\mathrm{CO}_{2}$ emissions were higher in the no-till farming system $\left(108.34 \pm 5.78 \mu \mathrm{mol} \mathrm{m}^{-2} \mathrm{~s}^{-1}\right)$ than in tillage farming systems $\left(104.62 \pm 4.56 \mu \mathrm{mol} \mathrm{m} \mathrm{m}^{-2} \mathrm{~s}^{-1}\right)$, the difference was not significant at the significance level of 0.05 . A significant difference was detected between the tillage systems in August 2021, which agrees with the results observed in the previous year. The soil $\mathrm{CO}_{2}$ emissions from no-till farming systems were $108.90 \pm 4.69 \mu \mathrm{mol} \mathrm{m} \mathrm{m}^{-2} \mathrm{~s}^{-1}$, while the emissions of soil in tillage farming system were $83.54 \pm 4.30 \mu \mathrm{mol} \mathrm{m} \mathrm{m}^{-2} \mathrm{~s}^{-1}$.

\section{Pearson correlation analysis - Relationships among soil $\mathrm{CO}_{2}$ emissions and soil and environmental proper- ties under different farming systems in 2020 and 2021}

The Pearson correlation analyses showed different results in the impact of soil and environmental properties on soil $\mathrm{CO}_{2}$ emissions under different farming systems (Table 4). The correlation between gravimetric water content (GWC) and soil $\mathrm{CO}_{2}$ emissions ( $\mathrm{r}=0.33$ ), soil penetration resistance $(\mathrm{PR})$ and soil $\mathrm{CO}_{2}$ emissions ( $\left.\mathrm{r}=0.47\right)$ was positive and weak in the 
no-tillage farming system in 2020. A moderate positive correlation was found between total organic carbon (TOC) and soil $\mathrm{CO}_{2}$ emissions ( $\left.\mathrm{r}=0.61\right)$, air temperature (AT) and soil $\mathrm{CO}_{2}$ emissions $(\mathrm{r}=0.69)$, while the moderate negative correlation occurred between air pressure (AP) and soil $\mathrm{CO}_{2}$ emissions $(\mathrm{r}=0.72)$. On the contrary, no correlation $(\mathrm{r}< \pm 0.29)$ was observed between the soil $\mathrm{CO}_{2}$ emissions and any soil and environmental properties in the no-tillage farming system in 2021.

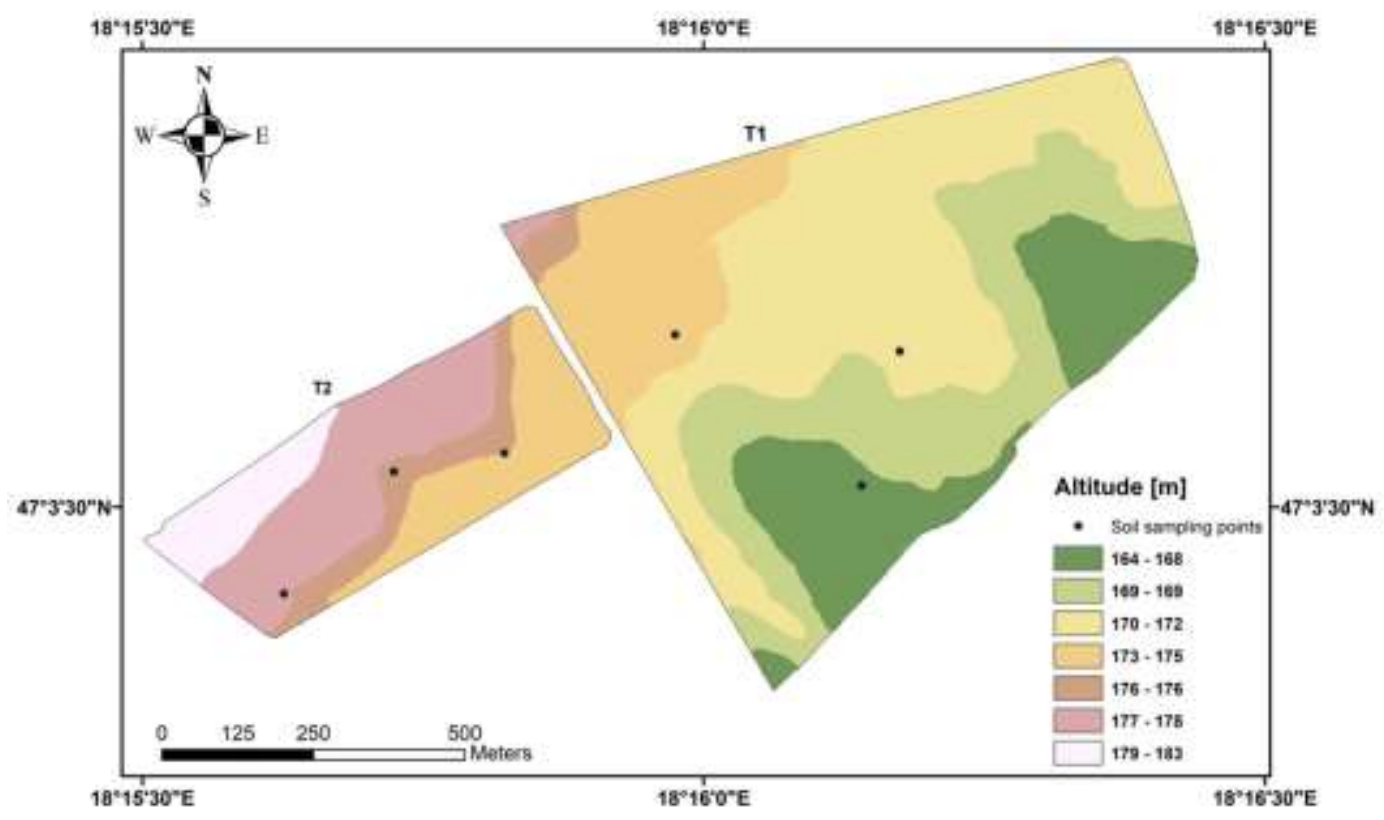

Figure 1. Soil sampling points

Table 4. Pearson correlation coefficients between soil $\mathrm{CO}_{2}$ emissions and other variables for each field in 2020 and 2021

\begin{tabular}{lrrrr}
\hline \multicolumn{5}{c}{ Soil $\mathrm{CO}_{2}$ emissions } \\
\hline Farming systems & \multicolumn{2}{c}{ No-tillage } & \multicolumn{2}{c}{ Tillage } \\
\hline Years & 2020 & 2021 & 2020 & 2021 \\
\hline Soil CO 2 emissions & 1 & 1 & 1 & 1 \\
TOC & 0.612 & -0.287 & $-0,843^{*}$ & 0,247 \\
GWC & 0.325 & 0.100 & $0,789 * *$ & $0,761^{*} *$ \\
PR & 0.465 & 0.006 & $-0,055$ & $-0,851^{*}$ \\
AT & 0.694 & -0.068 & $-0,687$ & $-0,893^{*}$ \\
AP & -0.721 & 0.028 & 0,688 & $-0,890^{*}$ \\
\hline
\end{tabular}

$*$, significance level at $\mathrm{p}=0.05 ; * *$, significance level at $\mathrm{p}=0.1$

In the tillage farming system, a significant $(\mathrm{p}=0.05)$ strong negative correlation ( $\mathrm{r}=-0.84$ ) was found between TOC and soil $\mathrm{CO}_{2}$ emissions in 2020. A moderate negative correlation was observed between AT and soil $\mathrm{CO}_{2}$ emissions ( $\left.\mathrm{r}=-0.69\right)$, while a moderate positive correlation was between soil $\mathrm{CO}_{2}$ emissions and AP $(r=0.69)$ and significant $(\mathrm{p}=0.1)$ moderate GWC ( $\mathrm{r}=0.79)$. A negligible correlation was determined between soil $\mathrm{CO}_{2}$ emissions and $\mathrm{PR}(\mathrm{r}=0.06)$ in 2020. A significant $(\mathrm{p}=0.05)$ strong and negative correlation occurred between soil $\mathrm{CO}_{2}$ emissions and PR ( $\left.\mathrm{r}=-0.85\right)$, AT $(\mathrm{r}=-0.89)$ and AP ( $\mathrm{r}=-0.89)$ in 2021. Soil $\mathrm{CO}_{2}$ emissions significant $(\mathrm{p}=0.1)$ moderate positively correlated with GWC $(\mathrm{r}=0.76)$.
TOC was also positively correlated with soil $\mathrm{CO}_{2}$ emissions, but its strength was weak $(r=0.25)$ in the tillage farming system in 2021 .

\section{Comparison of the quality of the soil $\mathrm{CO} 2$ emissions prediction models in different tillage systems and years}

Four models were developed according to the farming systems and years (Table 5). The developed regression model for the tillage farming system in 2020 (Till20) was based on TOC, GWC and PR, while the model for the no-till farming 
system in 2020 (No-Till20) consisted of AT and GWC. The TOC and GWC variables show inverse relationships, while PR directly relates to soil $\mathrm{CO}_{2}$ emissions in the Till20 model. In contrast to the Till20 model, as the GWC and AT increase, the soil $\mathrm{CO}_{2}$ emissions also increase in the No-till20 model. The coefficient of determination $\left(\mathrm{R}^{2}\right)$ was 0.9243 for the
Till20 model. For the No-Till20 model, this parameter was 0.7967. The results revealed that the soil $\mathrm{CO}_{2}$ emissions responded significantly $(\mathrm{p}<0.05)$ to the change of TOC, GWC and AT for the Till20 model and of GWC and AT for the NoTill20 model (Figures 2 and Figure 3).

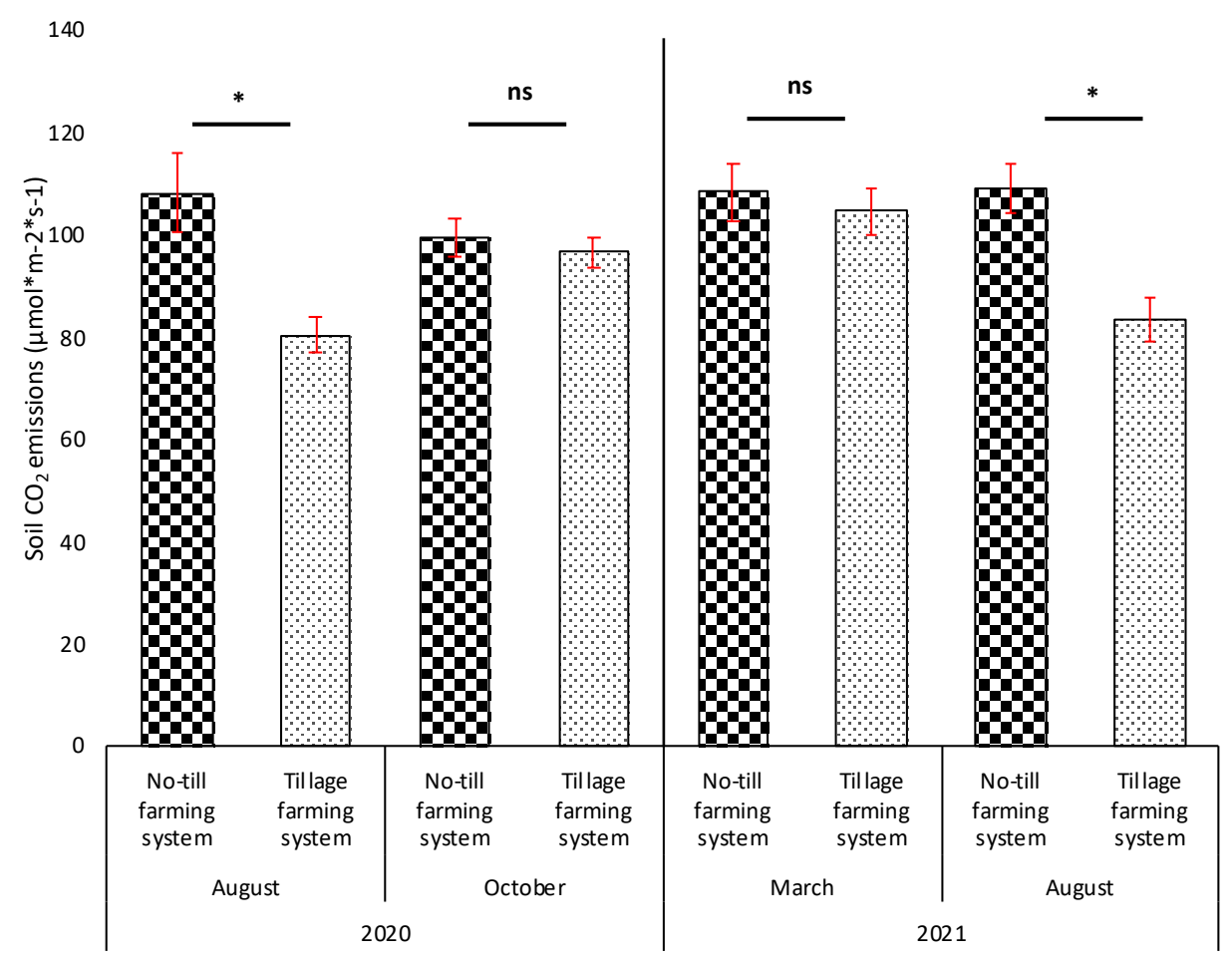

Figure 2. Two-tailed Student's T-test shows the difference in the soil $\mathrm{CO}_{2}$ emissions between different tillage systems in 2020 and 2021. Bar graphs are representative of the mean. Error bars indicate the standard error of the mean (SEM). (*, significant at $\mathrm{p}=0.05$; ns, not significant at $\mathrm{p}=0.05)$.

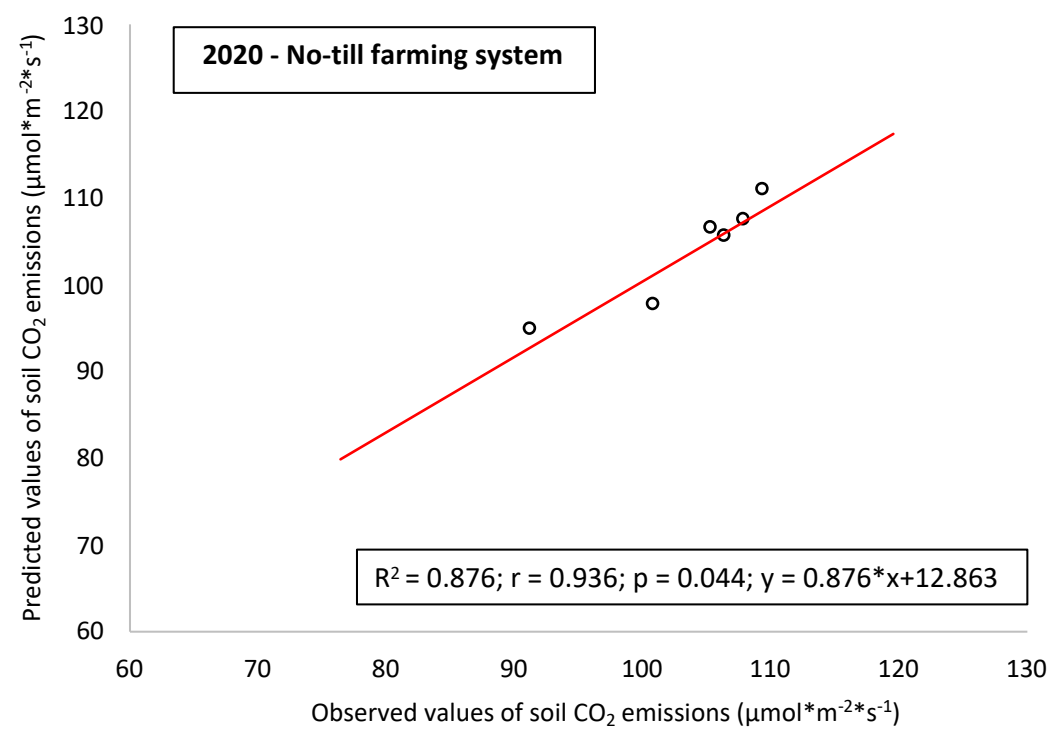

Figure 3. The scatter plot between observed and predicted values according to the No-Till20 model 
The explanative power of the two models is similar if adjusted $\mathrm{R}^{2}$ is studied $\left(\mathrm{R}^{2}\right.$ adj). The adjusted regression coefficient is
$92.43 \%$ in the Till20 model and $79.67 \%$ in the No-Till20 model (Table 5).

Table 5. Regression coefficients and probability levels for the generated models

\begin{tabular}{|c|c|c|c|c|c|c|c|c|c|c|c|c|}
\hline \multirow{5}{*}{$\frac{\frac{n}{0}}{\frac{\pi}{3}}$} & \multicolumn{12}{|c|}{ Models } \\
\hline & \multicolumn{6}{|c|}{2020} & \multicolumn{6}{|c|}{2021} \\
\hline & \multicolumn{3}{|c|}{$\begin{array}{l}\text { Tillage farming } \\
\text { system (Till20) }\end{array}$} & \multicolumn{3}{|c|}{$\begin{array}{l}\text { No-tillage farming } \\
\text { system (No-Till20) }\end{array}$} & \multicolumn{3}{|c|}{$\begin{array}{l}\text { Tillage farming } \\
\text { system (Till21) }\end{array}$} & \multicolumn{3}{|c|}{$\begin{array}{l}\text { No-tillage farming } \\
\text { system (No-Till21) }\end{array}$} \\
\hline & \multicolumn{3}{|c|}{$\begin{array}{c}\mathrm{R}_{\text {adj }}^{2}=0.9243 \\
\text { Constant }=387.8673 \\
\mathrm{p}=0.0456\end{array}$} & \multicolumn{3}{|c|}{$\begin{array}{c}\mathrm{R}_{\text {adj }}^{2}=0.7967 \\
\text { Constant }=-59.9130 \\
\mathrm{p}=0.0437\end{array}$} & \multicolumn{3}{|c|}{$\begin{array}{c}\mathrm{R}_{\text {adj }}^{2}=0.7467 \\
\text { Constant }=202.7162 \\
\mathrm{p}=0.0166\end{array}$} & \multicolumn{3}{|c|}{$\begin{array}{c}\mathrm{R}_{\text {adj }}^{2}=0.6938 \\
\text { Constant }=-150535.6063 \\
\mathrm{p}=0.0787\end{array}$} \\
\hline & $\mathrm{b}$ & $\mathrm{p}$ & Sig & $\mathrm{b}$ & $\mathrm{p}$ & Sig & b & $\mathrm{p}$ & Sig & b & $\mathrm{p}$ & Sig \\
\hline TOC & -44.8505 & 0.0414 & $*$ & - & - & - & - & - & - & - & - & - \\
\hline $\mathrm{AP}$ & - & - & - & - & - & - & - & - & - & 1.5164 & 0.0357 & $*$ \\
\hline GWC & -910.1244 & 0.0801 & $* *$ & 318.7649 & 0.0538 & $* *$ & - & - & - & - & - & - \\
\hline PR & 53.6786 & 0.0538 & $* *$ & - & - & - & - & - & - & - & - & - \\
\hline $\mathrm{AT}$ & - & - & - & 5.5718 & 0.0209 & $*$ & -5.3411 & 0.0166 & $*$ & -75.1846 & 0.0355 & $*$ \\
\hline
\end{tabular}

Determination of the level of statistical significance: * significant at $\mathrm{p}=0.05 ; * *$ significant at $\mathrm{p}=0.1 ;-$ not available in the model

The linear regression model for the tillage farming system in 2021 (Till21) was based on AT. By contrast, the AP and the AT independent variables are the basis of the model for notillage farming systems in 2021 (No-Till21). The coefficient of AT variable is negative and shows an inverse relationship between air temperature and soil $\mathrm{CO}_{2}$ emissions for the Till21 model. In the case no-tillage farming system model (NoTill21), the AT variable also shows an inverse relationship with soil $\mathrm{CO}_{2}$ emissions. Hence, a direct relationship was determined between AP and soil $\mathrm{CO}_{2}$ emissions in the Notill21 model. The Till21 model explains $79.7 \%$ of the variation, while the No-Till21 model explains $81.6 \%$. Moreover, relationships between the observed and predicted soil $\mathrm{CO}_{2}$ emission values were statistically significant at $\mathrm{p}=0.05$ level for Till 21 while at $\mathrm{p}=0.1$ for the No-Till20 (Figure 4 and Figure 5).

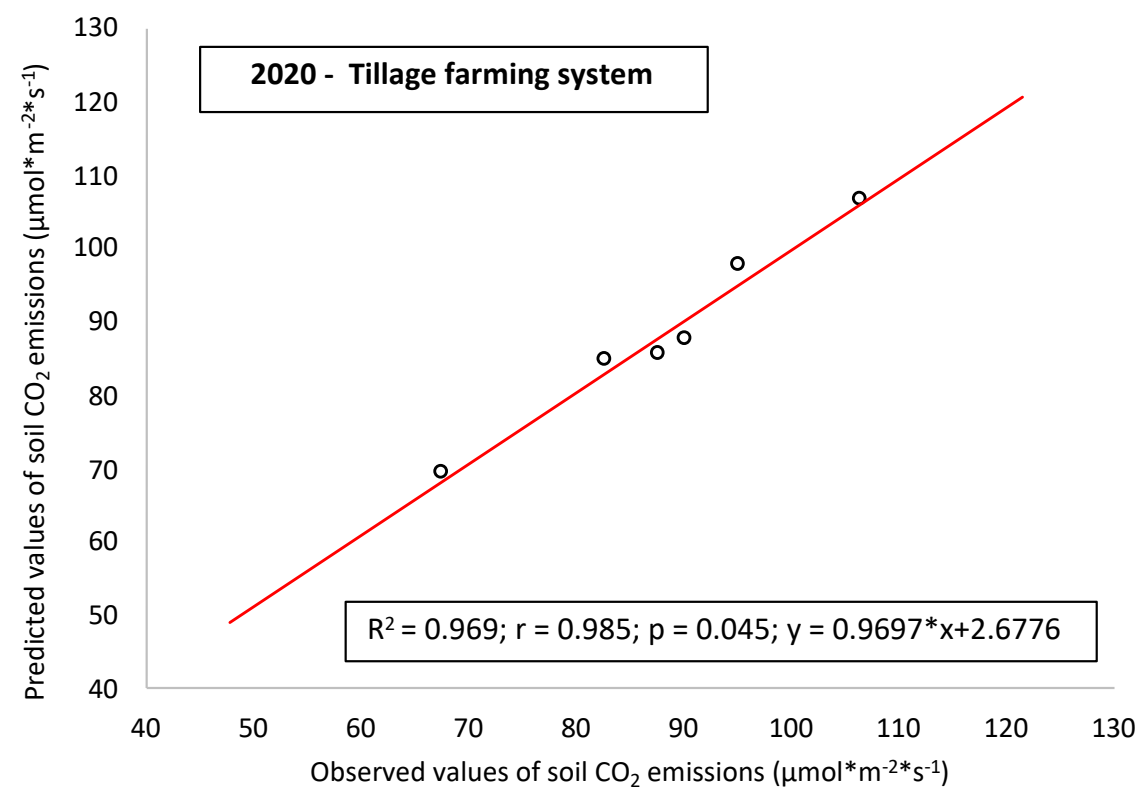

Figure 4. The scatter plot between observed and predicted values according to the Till20 model 


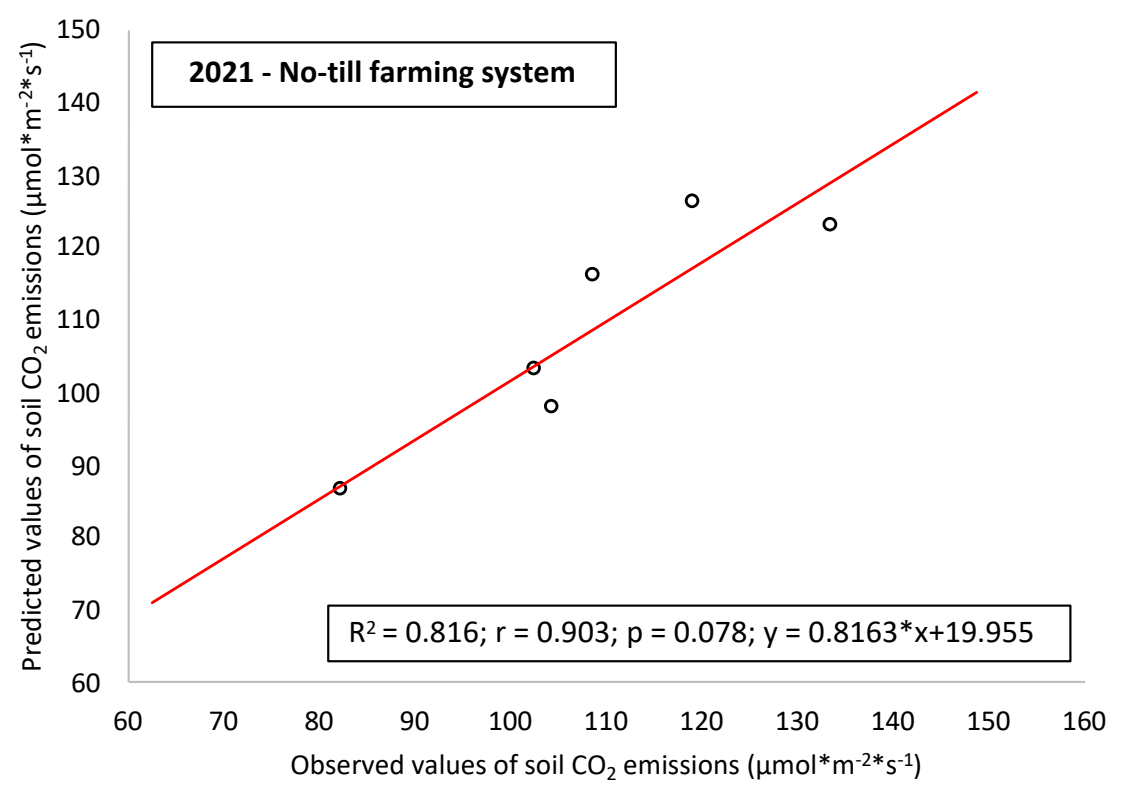

Figure 5. The scatter plot between observed and predicted values according to the No-Till21 model

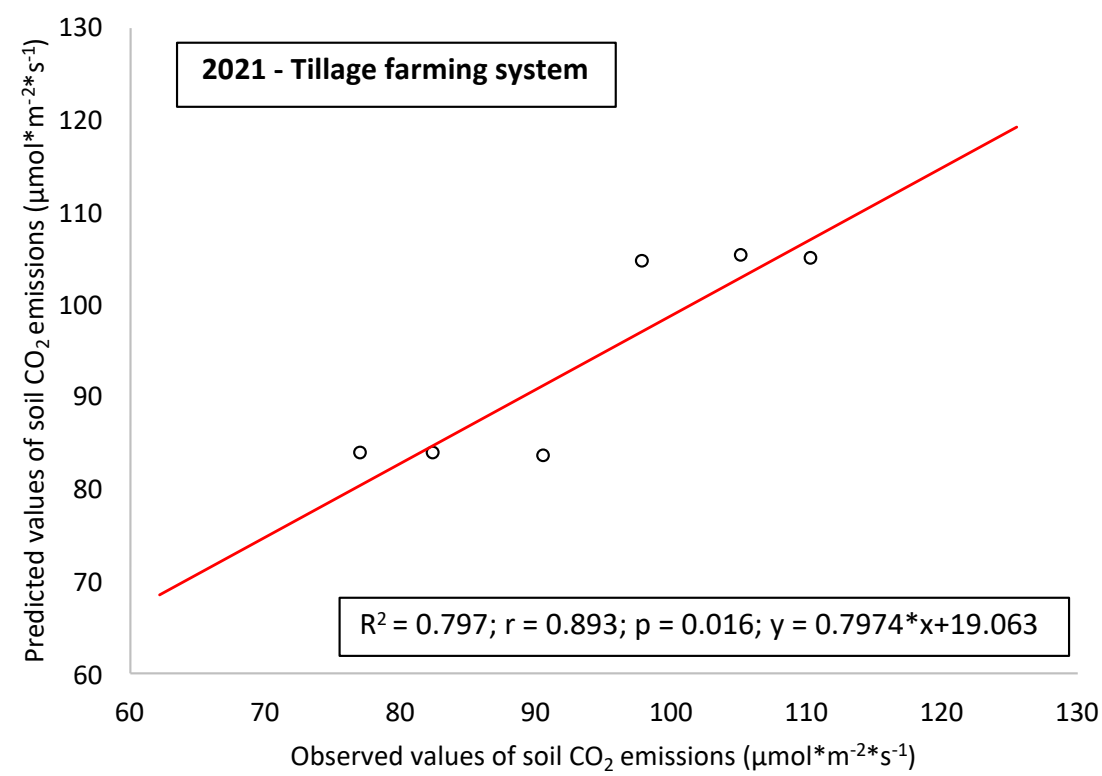

Figure 6. The scatter plot between observed and predicted values according to the Till 21 model

The explanative power of the two models is similar if adjusted $\mathrm{R}^{2}$ is studied: 0,7467 and 0.6938 , respectively (Table 5). Multicollinearity was not identified between the independent variable in the models, because the VIF threshold values were not higher than 10 in any models. It indicates the total absence of collinearity between these variables and other predictors in the models (Table 6.).

\section{Forecasting properties of linear models}

The proper functioning of the Till20, Till21, No-Till20 and No-Till21 models was verified by comparing the observed with the predicted soil $\mathrm{CO}_{2}$ emissions. These results suggested that the proposed models performed well for all years and both management practices. The four forecast error metrics showed that the models developed for 2020, regardless of the management practices, predicted much more precisely the soil $\mathrm{CO}_{2}$ emissions than in 2021.

It is indicated mainly by the lower RMSE and MAE values. However, the MAPE values did not reach the $10 \%$ level for either model (Table 7). Thus, the degree of goodness-of-fit of the model is perfect for all cases (Peng et al., 2017). 


\section{DISCUSSION}

\section{The overall influence of tillage on soil $\mathrm{CO}_{2}$ emissions}

Our results show that the change of tillage practices significantly impacts the soil $\mathrm{CO}_{2}$ emissions, but it varies across the growing season. This study reported that the untilled soil had significantly greater $\mathrm{CO}_{2}$ emissions (2623\%) than the tilled soil in August 2020 and 2021. Although the untilled soil had greater $\mathrm{CO}_{2}$ emissions than tilled soil in October 2020 and March 2021, differences were not significant between the tillage systems (Figure 1.). The higher $\mathrm{CO}_{2}$ emissions are attributed to the significantly higher soil moisture content and increased soil penetration resistance (Table 3.). In the case of soil $\mathrm{CO}_{2}$ emissions, the results from the literature do not always agree with our findings.
Mohammed et al., (2021) and Ussiri and Lal, (2009) from maise cultivation and Omonode et al., (2007) in maize and corn-soybean rotations observed greater $\mathrm{CO}_{2}$ emissions from tilled than from no-tilled soil, which is in alignment with the comprehensive meta-analysis results observed by Abdalla et al., (2016). This is explained the fact that the (i) cultivation process separates soil aggregates into small particles, which directly accelerates soil aeration and microbiological activities (de Oliveira Silva et al., 2019); (ii) soil management activities, including tillage, sowing, harvesting and fertilisation have a direct impact on soil moisture and biomass, which affects soil carbon emissions (Barcza et al., 2009). Our results refer to other studies that have also reported lower soil $\mathrm{CO}_{2}$ emissions under tillage compared to conservation (no-tillage) tillage systems (Oarts et al., 2007; Cheng-Feng et al., 2012; Plaza-Bonilla et al., 2014).

Table 6. Variance Inflator Factor (VIF) value between the independent variable in the generated models.

\begin{tabular}{cccc}
\hline & Till20 & No-till20 & No-till21 \\
\hline TOC - GWC & 7.8304 & - & - \\
TOC-PR & 0.9501 & - & - \\
GWC-PR & 0.8191 & - & - \\
GWC-AT & - & 1.0310 & - \\
AP-AT & - & - & 7.6671 \\
\hline
\end{tabular}

Table 7. Ex post predictive measures in models

\begin{tabular}{lrrrr}
\hline \multirow{2}{*}{ Error Type } & \multicolumn{5}{c}{ Model } \\
\cline { 2 - 5 } & 2020_Till & 2020_No-Till & 2021_Till & 2021_No-Till \\
\hline RAE $[-]$ & 0.023 & 0.021 & 0.056 & 0.061 \\
\hline RMSE $\left[\mu \mathrm{mol}^{*} \mathrm{~m}^{-2 *} \mathrm{~s}^{-1}\right]$ & 2.049 & 2.138 & 5.314 & 6.701 \\
\hline MAE $\left[\mu \mathrm{mol}^{*} \mathrm{~m}^{-2 *} \mathrm{~s}^{-1}\right]$ & 1.815 & 1.766 & 4.549 & 5.862 \\
\hline MAPE $[\%]$ & 2.111 & 1.767 & 4.957 & 5.299 \\
\hline
\end{tabular}

\section{Impact of environmental on $\mathrm{CO}_{2}$ emissions}

The outcomes of this study revealed that proximal and distal drivers have a significant impact on the soil $\mathrm{CO}_{2}$ emissions, but it differs according to year and farming systems. In 2020, the soil $\mathrm{CO}_{2}$ emissions in tillage systems depended on the change of total organic carbon (TOC) content, gravimetric water content (GWC) and soil penetration resistance (PR), while the main driving factors of soil $\mathrm{CO}_{2}$ emissions were GWC and air temperature (AT) in No-tillage farming system. In contrast, the environmental factors (air pressure and temperature) played a significant role in the change of $\mathrm{CO}_{2}$ emissions in both farming systems (Tables 4. and 5). The positive impact of air temperature and pressure on soil $\mathrm{CO}_{2}$ emissions is well studied (2013; Almaraz et al., 2009; Oertel et al., 2016; Smith et al., 2018), Rey et al., (2002) have also similarly reported that the soil $\mathrm{CO}_{2}$ emissions vary according to the change of the season. In this context, the soil $\mathrm{CO}_{2}$ emissions is lower during the dry summers, highlighting the importance of soil moisture content. Our results show (Table
4.) similarity with the findings of Reicosky et al., (2008) and Zhang et al., (2006), that is, the lower air pressure supports the higher soil emissions due to the reduced counter-pressure on the soil.

\section{CONCLUSION}

In this research, $\mathrm{CO}_{2}$ emissions were measured in two different farming systems located in Fejér county, Hungary. The first was a tillage farming system, while the second was a no-tillage farming system. This research showed that $\mathrm{CO}_{2}$ emissions were higher than tillage farming systems in the notillage farming system. Considering the collecting of different environmental and soil factors and their impact on soil emissions, the findings of this study could help scientists and decision-makers to predict the soil $\mathrm{CO}_{2}$ emissions. Thus, contributing to the drawing up mitigation strategies to minimize the total GHG emissions from the agricultural sector. 


\section{ACKNOWLEDGEMENTS}

The research presented in this paper was financed by Ministry of Human Capacities under agreement no. NTP-NFTÖ-20-B0151 and by the European Social Fund (EFOP-3.6.3VEKOP-16-2017-00008 „Innovative Scientific Institutions in Domestic Agricultural Higher Education" project). The authors greatly acknowledge the valuable contributions from colleagues of the "Research Area Excellence Program - 2019 (TUDFO/51757/2019-ITM)" and University of Györ.

\section{REFERENCES}

Abdalla, K., Chivenge, P., Ciais, P., Chaplot, V., 2016. Notillage lessens soil $\mathrm{CO}_{2}$ emissions the most under arid and sandy soil conditions: results from a meta-analysis. Biogeosciences 13(1), pp.3619-3633.

DOI: $10.5194 /$ bgd-12-15495-2015

Almaraz, J.J., Zhou, X., Mabood, F., Madramootoo, C., Rochette, P., Ma, B.L., Smith, D.L., 2009. Greenhouse gas fluxes associated with soybean production under two tillage systems in southwestern Quebec. Soil and Tillage Research 104(1), pp.134-139.

DOI: $\underline{10.1016 / \text { j.still.2009.02.003 }}$

Baker, J.M., Ochsner, T.E., Venterea, R.T., Griffis, T.J., 2007. Tillage and soil carbon sequestration - What do we really know? Agricult Ecosystems and Environ 118, pp.1-5.

DOI: $\underline{10.1016 / \text { j.agee.2006.05.014 }}$

Barcza, Z., Haszpra, L., Somogyi, Z., Hidy, D., Lovas, K., Churkina, G., Horvath, L., 2009. Estimation of the biospheric carbon dioxide balance of Hungary using the BIOME-BGC model. Idojaras 113(3), pp.203-209.

Black, C.A., 1965. Methods of Soil Analysis: Part I, Physical and mineralogical properties. American Society of Agronomy, Madison, Wisconsin.

Bockisch, F.J., 2010. Bewertung von Verfahren der ökologischen und konventionellen landwirtschaftlichen Produktion im Hinblick auf den Energiewinsatz und bestimmte Schadgasemissionen: Studie als Sondergutachten im Auftrag des Bundesministeriums für Ernährung, Landwirtschaft. Braunschweig Bundesforschungsanst für Landwirtschaft, Darmstadt.

Busscher, W.J., Bauer, P.J., Frederick, J.R., 2002. "Recompaction of a coastal loamy sand after deep tillage as a function of subsequent cumulative rainfall." Soil and Tillage Research 68, pp.49-57.

DOI: $10.1016 /$ S0167-1987(02)00083-1

Buzás I., Daróczi S., Dódony I., Kálmán A., Kocsis I., Pártay G., and Rajkai K., 1993. Soil and agrochemical methodology book (in Hungarian). Budapest, Hungary. Inda 4231 Kiadó.

Campbell, D.J., O'Sullivan, M.F., 1991. The cone penetrometer in relation to trafficability, compaction and tillage. in Smith, K. A; Mullins, C.E. (Ed.) "Soil Analysis: Physical Methods". Marcel Dekker Inc., New York

Cheng-Fang, L., Dan-Na, Z., Zhi-Kui, K., Zhi-Sheng, Z., JinPing, W., Ming-Li, C., Cou-Gui, C., 2012. Effects of tillage and nitrogen fertilizers on $\mathrm{CH}_{4}$ and $\mathrm{CO}_{2}$ emissions and soil organic carbon in paddy fields of central China. PloS One 7(5), pp.e34642.

DOI: $\underline{10.1371 / \text { journal.pone. } 0034642}$

de Oliveira Silva, B., Moitinho, M.R., de Araujo Santos, G.A., Teixeira, D.D.B., Fernandes, C., La Scala Jr, N., 2019. Soil $\mathrm{CO}_{2}$ emission and short-term soil pore class distribution after tillage operations. Soil and Tillage Research, 186, pp.224-232.

DOI: $\underline{10.1016 / j . s t i l l .2018 .10 .019}$

Dunai, S., Posza, I., Varga-Haszonits, Z., 1968. Egyszerü módszer a tényleges evapotranszpiráció és a talaj vízkészletének meghatározására. I. A párolgás meteorológiája (in Hungarian). Öntözéses Gazdálkodás 4(2), pp.39-48.

FAO., 2020. Emissions due to agriculture. Global, regional and country trends 2000-2018. FAOSTAT Analytical Brief Series No 18. Rome

Fisher, R.A. 1925. Statistical Methods for Research Workers. Oliver and Boyd, Edinburgh, Scotland.

Gritsch, C., Zimmermann, M., Zechmeister-Boltenstern, S., 2015. Interdependencies between temperature and moisture sensitivities of $\mathrm{CO}_{2}$ emissions in European land ecosystems. Biogeosciences 12, pp.5981-5993.

DOI: $10.5194 /$ bgd-12-4433-2015

Groffman, P.M., Hardy, J.P., Driscoll, C.T., Fahey, T.J., 2006. Snow depth, soil freezing, and fluxes of carbon dioxide, nitrous oxide and methane in a northern hardwood forest. Global Change Biology 12(1), pp.1748-1760.

DOI: $10.1111 / \mathrm{j} .1365-2486.2006 .01194 . \mathrm{x}$

Hendrix, P., Han, C. R., and Groffman, P. 1988. Soil respiration in conventional and no-tillage agroecosystems under different winter cover crop rotations. Soil and Tillage Research 12, pp.135-148.

DOI: $\underline{10.1016 / 0167-1987(88) 90037-2}$

IPCC 2014. Climate Change 2014, Synthesis Report. Contribution of Working Group I, II and III to the Fifth Assessment Report of the Intergovernmental Panel on Climate Change. IPCC, Genova.

Jobbágy, G.E., Jackson B.R., 2000. The vertical distribution of soil organic carbon and its relation to climate and vegetation. Ecological Applications 10(2), pp.423-436.

DOI: $\underline{10.2307 / 2641104}$ 
Kutner, M.H., Nachtsheim, C. J., Neter, J., 2004. Applied Linear Regression Models (4th ed.). McGraw-Hill Irwin, New York.

Lal, R., Follett, R.F., Stewart, B.A., Kimble, J.M., 2007. Soil carbon sequestration to mitigate climate change and advance food security. Soil Science 172(12), pp.943-956.

DOI: $\underline{10.1097 / \mathrm{ss} .0 \mathrm{~b} 013 \mathrm{e} 31815 \mathrm{cc} 498}$

Levene, H., 1960. In Contributions to Probability and Statistics: Essays in Honor of Harold Hotelling, I. Olkin et al. eds., Stanford University Press, pp.278-292.

Lovenduski, N.S., Chatterjee, A., Swart, N.C., Fyfe, J.C., Keeling, R.F., Schimel, D., 2021. On the Detection of COVID-Driven Changes in Atmospheric Carbon Dioxide. Geophysical Research Letters 48(22), pp.1-8.

DOI: $10.1029 / 2021$ GL095396

Mohammed, S., Gill, A.R., Alsafadi, K., Hijazi, O., Yadav, K.K., Khan, A.H., 2021. An overview of greenhouse gases emissionsin Hungary. Journal of Cleaner Production 314(2021), pp.1-12.

DOI: $\underline{10.1016 / \text { j.jclepro.2021.127865 }}$

Montzka, S.A., Dlugokencky, E.J., Butler, J.H., 2011. Non$\mathrm{CO} 2$ greenhouse gases and climate change. Nature, 476 pp.43-50.

DOI: $10.1038 /$ nature 10322

MSZ-08-0210-77. 1977. A talaj szerves szén tartalmának meghatározása (in Hungarian). Magyar Szabványügyi Hivatal, Budapest MSZH-Nyomda.

Nawaz, A., Lal, R., Shrestha, R.K., Farooq, M., 2017. Mulching Affects Soil Properties and Greenhouse Gas Emissions Under Long-Term No-Till and Plough-Till Systems in Alfisol of Central Ohio. Land Degradation \& Development 28(2), pp.673-681.

DOI: $\underline{10.1002 / \mathrm{ldr} .2553}$

NEN5140, 1996. Geotechniek, Bepaling van de conusweerstand en de plaatselijke wrijvingsweerstand van grond. Elektrische sondeermethode. Nederlands Normalisatie-instituut

Niazian M., Sadat-Noori S.A., Abdipour M., 2018. Artificial neural network and multiple regression analysis models to predict essential oil content of ajowan (Carum copticum L.). Journal of Applied Research on Medicinal and Aromatic Plants 9(1), pp.124-131.

DOI: $\underline{10.1016 / \text { j.jarmap.2018.04.001 }}$

Novara A., Armstrong A., Gristina L., Semple K.T. Quinton J.N., 2012. Effects of soil compaction, rain exposure and their interaction on soil carbon dioxide emission. Earth Surface Processes and Landfroms 37(9), pp.994-999.

DOI: $\underline{10.1002 / \text { esp.3224 }}$
Oertel, C., Herklotz, K., Matschullat, J., Zimmermann, F., 2012. Nitric oxide emissions from soils: a case study with temperate soils from Saxony, Germany. Environmental Earth Sciences 66, pp.2343-2351.

DOI: $10.1007 / \mathrm{s} 12665-011-1456-3$

Oertel, C., Matschullat, J., Zurba, K., Zimmermann, F., Erasmi, S., 2016. Greenhouse gas emissions from soils-A review. Chemie der Erde-Geochemistry 76(3), pp.327-352. DOI: $\underline{10.1016 / \text { j.chemer.2016.04.002 }}$

Omonode, R.A., Vyn, T.J., Smith, D.R., Hegymegi, P., Gal, A., 2007. Soil carbon dioxide and methane fluxes from longterm tillage systems in continuous corn and corn-soybean rotations. Soil and Tillage Research 95(1-2), pp.182-195. DOI: $\underline{10.1016 / \text { j.still.2006.12.004 }}$

Oorts, K., Merckx, R., Gréhan, E., Labreuche, J., Nicolardot, B., 2007. Determinants of annual fluxes of $\mathrm{CO}_{2}$ and $\mathrm{N}_{2} \mathrm{O}$ in long-term no-tillage and conventional tillage systems in northern France. Soil and Tillage Research 95, pp.133-148. DOI: $10.1016 /$ j.still.2006.12.002

OWID, 2022. Emissions by Sector. Our World in Data, UK, Oxford.

Peng, J., Kim, M., Kim, Y., Jo, M., Kim, B., Sung, K., Lv, S., 2017. Constructing Italian ryegrass yield prediction model based on climatic data by locations in South Korea. Grassland Science 63, pp.184-195.

DOI: $10.1111 /$ grs. 12163

Piekutowska, M., Niedbała, G., Piskier, T., Lenartowicz, T., Pilarski, K., Wojciechowski, T., Pilarska, A.A., CzechowskaKosacka, A., 2021. The Application of Multiple Linear Regression and Artificial Neural Network Models for Yield Prediction of Very Early Potato Cultivars before Harvest. Agronomy 2021, 11(5), pp.1-17.

DOI: 10.3390 /agronomy 11050885

Plaza-Bonilla, D., Cantero-Martínez, C., Bareche, J., Arrúe, J.L., Alvaro-Fuentes, J., 2014. Soil carbon dioxide and methane fluxes as affected by tillage and $\mathrm{N}$ fertilization in dryland conditions. Plant and Soil 381(1-2), pp.111-130.

DOI: $\underline{10.1007 / \mathrm{s} 11104-014-2115-8}$

Powlson, D.S., Stirling, C.M., Jat, M.L., Gerard, B.G., Palm, C.A., Sanchez, P.A., Cassman, K.G. 2014. Limited potential of no-till agriculture for climate change mitigation. Nature Climate Change 4, pp.678-683.

DOI: $10.1038 /$ nclimate22921

Rastogi, M., Singh, S., and Pathak, H., 2002. Emission of carbon dioxide from soil. Current Science 82(5), pp.510-517.

Ray, R.L., Griffin, R.W., Fares, A., Elhassan, A., Awal, R., Woldesenbet, S., Risch, E., 2020. Soil $\mathrm{CO}_{2}$ emission in response to organic amendments, temperature, and rainfall. Scientific Reports 10(1), pp.1-14.

DOI: $\underline{10.1038 / \mathrm{s} 41598-020-62267-6}$ 
Reicosky, D.C., Gesch, R.W., Wagner, S.W., Gilbert, R.A., Wente, C.D., Morris, D.R., 2008. Tillage and wind effects on soil $\mathrm{CO}_{2}$ concentrations in muck soils. Soil and Tillage Research 99(1), pp.221-231.

DOI: $\underline{10.1016 / \text { j.still.2008.02.006 }}$

Ren, F., Zhang, X., Liu, J., Sun, N., Wu, L., Li, Z. \& Xu, M. 2017. A synthetic analysis of greenhouse gas emissions from manure amended agricultural soils in China. Scientific Reports 7(1), pp.1-13.

DOI: $\underline{10.1038 / \mathrm{s} 41598-017-07793-6}$

Rey, A., Pegoraro, E., Tedeschi, V., De Parri, I., Jarvis, P.G., Valentini, R., 2002. Annual variation in soil respiration and its components in a coppice oak forest in Central Italy. Global Change Biology 8(9), pp.851-866.

DOI: $10.1046 / \mathrm{j} .1365-2486.2002 .00521 . \mathrm{x}$

Schaufler, G., Kitzler, B., Schindlbacher, A., Skiba, U., Sutton, M.A., Zechmeister-Boltenstern, S., 2010. Greenhouse gas emissions from European soils under different land use: effects of soil moisture and temperature. European Journal of Soil Science 61(1), pp.683-696.

DOI: $\underline{10.1111 / \mathrm{j} .1365-2389.2010 .01277 . \mathrm{x}}$

Schlesinger, W.H., 1990. Evidence from chronosequence studies for a low carbon-storage potential of soils. Nature 348, pp.232-234.

DOI: $10.1038 / 348232 \mathrm{a} 0$

Sellam, V., Poovammal, E., 2016. Prediction of Crop Yield using Regression Analysis. Indian Journal of Science and Technology 9(38), pp.1-5.

DOI: $10.17485 / \mathrm{ijst} / 2016 / \mathrm{v} 9 \mathrm{i} 38 / 91714$
Smith, K.A., Ball, T., Conen, F., Dobbie, K.E., Massheder, J., Rey, A., 2018. Exchange of greenhouse gases between soil and atmosphere: interactions of soil physical factors and biological processes. European Journal of Soil Science 69(1), pp.10-20.

DOI: $10.1111 /$ ejss. 12539

Smith, P., Martino, D., Cai, Z., Gwary, D., Janzen, H., Kumar, P., McCarl, B., Ogle, S., O’Mara, F., and Rice, C., 2008. Greenhouse gas mitigation in agriculture, Philosophical Transactions of the Royal Society B 363(1492), pp.789-813. DOI: $\underline{10.1098 / \text { rstb.2007.2184 }}$

Tubiello, F.N., Salvatore, M., Rossi, S., Ferrara, A., Fitton, N., Smith, P., 2013. The FAOSTAT database of greenhouse gas emission from agriculture. Environmental Research Letter. 8, pp.1-11.

DOI: $\underline{10.1088 / 1748-9326 / 8 / 1 / 015009}$

U.S.EPA 2012. Global anthropogenic non- $\mathrm{CO}_{2}$ greenhouse gas emissions: 1990-2030. EPA, Washington DC.

Ussiri, D.A.N., Lal, R., 2009. Long-term tillage effects on soil carbon storage and carbon dioxide emissions in continuous corn cropping system from an alfisol in Ohio. Soil and Tillage Research 104, pp.39-47.

DOI: $\underline{10.1016 / \text { j.still.2008.11.008 }}$

Zhang D., Sun X., Zhou G., Yan J., Wang Y., Liu S., Zhou C., Liu J., Tang X., Li J., Zhang Q., 2006. Seasonal dynamics of soil $\mathrm{CO}_{2}$ effluxes with responses to environmental factors in lower subtropical forests of China. Science in China Series D: Earth Sciences 49(2), pp.139-149.

DOI: $\underline{10.1016 / \text { j.foreco.2011.06.015 }}$

(C) 2022 by the author(s). This article is an open access article distributed under the terms and conditions of the Creative Commons Attribution (CC BY) license (http://creativecommons.org/licenses/by/4.0/). 